\title{
Buffer-induced, selective mono-C-alkylation of phloroglucinol: application to the synthesis of an advanced intermediate of catechin
}

\author{
Arnaud Gissot, ${ }^{\mathrm{a}, \mathrm{b}}$ Alain Wagner, ${ }^{\text {a* }}$ and Charles Mioskowski, ${ }^{a *}$ \\ * Corresponding authors. Tel.: +33-3-88-67-68-63; fax: +33-3-88-67-88-91; \\ e-mail address: alwag@bioorga.u-strasbg.fr; mioskowsi@bioorga.u-strasbg.fr
}

Keywords: Flavonoids; Polyphenol compounds; Phloroglucinol; Alkylation; Synthetic methodology.

aLaboratoire de Synthèse bioorganique, Université Louis Pasteur de Strasbourg, UMR 7514 du CNRS, Faculté de Pharmacie, 74 route du Rhin-BP 24-F-67401, Illkirch-Graffenstaden, France ${ }^{\text {b}}$ The Scripps Research Institute, MB 210, 10550 North Torrey Pines Rd, 92037 La Jolla, CA, USA.

Abstract-A straightforward mono-selective and C-specific alkylation of phloroglucinol with activated alkyl halides is presented. The use of water as solvent limits the amount of over-alkylated by-products. Provided some minor changes in the experimental conditions, hydrophobic cinnamyl halides can also be reacted, thus giving a direct access to advanced intermediates of natural flavonoids.

\section{Introduction}

The flavonoids are a family of polyphenolic compounds found in the plant kingdom. They feature interesting antioxidative properties responsible for the health-benefits associated with a diet rich in vegetables and are found in large quantities in red wines and green teas. ${ }^{1}$ However, due to the lack of reliable chemical methods for their synthesis, only natural extracts with ill-defined chemical compositions are usually evaluated for their biological activity. Undoubtedly, the poor overall stability of flavonoids is responsible for the lack of general methods for their chemical synthesis. Consequently, protecting-group free syntheses of polyphenols are scarce. The target molecules cannot often withstand the conditions required for removal of most of the conventional protecting groups. To the best of our knowledge, only benzyl derivatives have been used successfully as protecting groups in the total synthesis of natural flavonoids. ${ }^{2}$ The phloroglucinol motif (1,3,5-benzenetriol) is ubiquitous in all natural flavonoids structures. As such, it constitutes the ultimate starting material en route to the synthesis of elaborated (un)natural polyphenols. Unfortunately, the benzylation of phloroglucinol is not selective and gives a mixture of both $\mathrm{O}$ - and Cbenzylated products. ${ }^{3}$ Hence, many efforts have been aimed at methods to achieve the specific mono-, di-, or tri-O-benzylation of phloroglucinol. ${ }^{4}$ These methods are multi-step and require careful control of the reaction conditions. Most interestingly, the selective C-alkylation of phloroglucinol has never been reported, the only examples found in the literature concerning reactions with protected versions of phloroglucinol. ${ }^{5}$ Though apparently simple, this transformation offers several synthetic challenges. As phloroglucinol contains six nucleophilic sites, an ideal reaction will be mono- and C-specific. Undoubtedly, such a reaction would constitute an easy and straightforward approach toward the synthesis of natural unprotected flavonoids like catechin whose retrosynthesis is depicted in the following scheme. Our approach to catechin is very concise and involves the intramolecular ring closing between a phenol of the phloroglucinol core and the epoxide as the last step. This epoxide intermediate is ideally synthesized in two steps starting from the selective alkylation of phloroglucinol followed by the epoxidation of the double bond. In this communication, we show that phloroglucinol can be C-specifically and mono-selectively alkylated with various activated alkyl halides in buffered aqueous solutions. The use of buffered aqueous solutions as the reaction media proved crucial to control the regio-selectivity of the reaction.

\section{Results and discussion}

The reaction of phloroglucinol with allyl bromide was investigated first (Table 1, entries 1-6). Interestingly, phloroglucinol is nucleophilic enough to undergo alkylation in aqueous ethanol in the absence of base, with allyl phloroglucinol 1a being obtained in $36 \%$ yield (entry 1 ). No products resulting from the 0 -alkylation of phloroglucinol are detected in the crude reaction mixture. However, the reaction is not mono-selective and gives substantial amounts of the di-alkylated product $2 a$. The extent of mono-alkylation as well as the yield of the desired compound 1a is greatly improved in pure water (entry 2). The lower solubility of $2 \mathrm{a}$ in water in comparison to the starting phloroglucinol may account for this better selectivity.

Although 1a is obtained in good yield $(68 \%$, entry 2$)$ in water, the $\mathrm{pH}$ of the reaction medium becomes increasingly acidic as the allyl phloroglucinol is formed. Since most of the polyphenols are $\mathrm{pH}$-sensitive, milder conditions are required for the synthesis of 
more elaborate adducts. Using stoichiometric amounts of sodium hydroxide, the phenolate of phloroglucinol is formed and the reaction is faster (entry 3 ).<smiles>Oc1cc(O)c2c(c1)O[C@H](c1ccc(O)c(O)c1)C(O)C2</smiles>

(+)-catechin<smiles>[R2]Oc1ccc(C2OC2Cc2c(O)cc(O)cc2O)cc1[R2]</smiles>

$\mathrm{R}=\mathrm{H}$ or $\mathrm{Bn}$<smiles>C=CC</smiles><smiles>[R]Oc1ccccc1OC</smiles>

Scheme 1. Retrosynthetic scheme of catechin.

Table 1. Conditions tested for the alkylation of phloroglucinol in water<smiles>Oc1cc(O)cc(Br)c1</smiles>

phloroglucinol

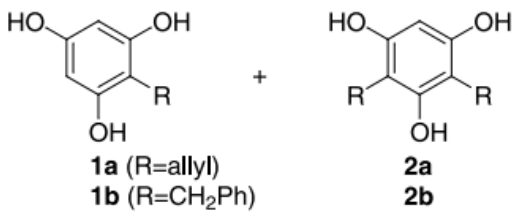

b

\begin{tabular}{|c|c|c|c|c|c|c|c|c|}
\hline \multirow[t]{2}{*}{ Entry } & \multirow[t]{2}{*}{ Base (equiv.) } & \multirow[t]{2}{*}{$x$} & \multirow[t]{2}{*}{$\mathrm{R}$} & \multirow[t]{2}{*}{ Solvent } & \multirow[t]{2}{*}{$T\left({ }^{\circ} \mathrm{C}\right)$} & \multirow[t]{2}{*}{ Time (h) } & \multicolumn{2}{|c|}{ Yields $(\%)^{\mathrm{a}}$} \\
\hline & & & & & & & 1 & 2 \\
\hline 1 & None & 5 & Allyl & $\mathrm{EtOH}_{40 \%}$ & 20 & 72 & 36 & 30 \\
\hline 2 & None & 5 & Allyl & $\mathrm{H}_{2} \mathrm{O}$ & 20 & 72 & 68 & 23 \\
\hline 3 & $\mathrm{NaOH}(1)$ & 1.1 & Allyl & $\mathrm{H}_{2} \mathrm{O}$ & 20 & 12 & 45 & 17 \\
\hline 4 & $\mathrm{NaOH}(2)$ & 1.1 & Allyl & $\mathrm{H}_{2} \mathrm{O}$ & 20 & 5 & n.d. ${ }^{b}$ & \\
\hline 5 & Buffer $^{c}$ & 4 & Allyl & $\mathrm{H}_{2} \mathrm{O}$ & 20 & 4 & 62 & 24 \\
\hline 6 & Buffer $^{c}$ & 4 & Allyl & $\mathrm{H}_{2} \mathrm{O}$ & 10 & 10 & 35 & 12 \\
\hline 7 & Buffer $^{c}$ & 2 & Benzyl & $\mathrm{H}_{2} \mathrm{O}$ & 20 & 4 & 54 & 21 \\
\hline 8 & $\mathrm{NaOH}(2)$ & 2 & Benzyl & $\mathrm{EtOH}$ & 20 & 4 & 40 & 26 \\
\hline 9 & TEA (3) & 2 & Benzyl & THF & 20 & 5 & 42 & 23 \\
\hline
\end{tabular}

Isolated yields.

Not determined, see text.

' Phosphate buffer $0.2 \mathrm{M}, \mathrm{pH} 7.8$

Yet, the mono-alkylation selectivity is low. This can be ascribed to the better solubility of the phenolate of $1 \mathrm{a}$ in water in comparison to its neutral form. Consequently, $1 \mathbf{a}$ is more likely to over-react in basic solutions and lesser monoselectivity is observed (entry 3). A complex mixture of products is obtained with excess quantities of base (entry 4). Partial migration of the double bond of $\mathbf{1 a}$ and $\mathbf{2 a}$ in (conjugate) benzylic position takes place under these conditions. Alternatively, use of a buffered, ca. neutral, aqueous solution proved very successful. Since the $\mathrm{pH}$ is maintained throughout the course of the reaction, the reaction time is short and the yield of 1a remains quite good (entry 5). Reducing the reaction temperature to $10^{\circ} \mathrm{C}$ not only slows product formation but also results in lower selectivity and overall yield (entry 6). Under the same conditions ( $0.2 \mathrm{M}$ phosphate buffer, $\mathrm{pH}$ $7.8,25^{\circ} \mathrm{C}$ ), the reaction of phloroglucinol with benzyl bromide gave $\mathbf{1 b}$ and $\mathbf{2} \mathbf{b}$ in 54 and $21 \%$ yield, respectively. As for allyl bromide (results not shown), no O-benzylated phloroglucinol was obtained in ethanol or THF (entry 8 and 9), ${ }^{6}$ and the reaction must be carried out in DMF to observe the formation of benzyl ethers (results not shown). ${ }^{7}$ Hence, water does not influence the C-selectivity of the reaction. Indeed, both the phloroglucinol and activated alkyl halides are known to favor C-alkylation..$^{8,9}$ This is in sharp contrast to the reaction of non-activated alkyl bromides with phloroglucinol where water has a marked influence both on the $\mathrm{C}$ - and on the mono-selectivity. ${ }^{10}$ The reaction of phloroglucinol with cinnamyl halides (Table 2 ) readily gives access to the skeleton of natural flavonoids (Scheme 1). Yet, these adducts are quite acid-sensitive. This may in turn explain why the synthesis of simple intermediates like $1 \mathrm{c}$ have only been reported in a low $30 \%$ yield, ${ }^{9,11}$ or not achieved at all. ${ }^{12}$ The reaction of cinnamyl halides is actually even more challenging. In addition to the classical mono- and C-/O-alkylation issues encountered so far with allyl and benzyl halides, cinnamyl halides can give two additional regioisomers upon reaction with a nucleophile. Indeed, both regioisomers $\mathbf{1 c}$ and $\mathbf{1} \mathbf{d}$ are formed in equal amounts under our buffered reaction conditions (Table 2 , entry 1 ). We found the desired isomer $\mathbf{1 c}$ is cleanly obtained in a mixture of ethanol and aqueous sodium hydroxide. Several factors may account for this selectivity. First, the dielectric constant of the solution decreases with increasing amounts of ethanol. Hence, the dissociation of ion pairs is less likely in solutions containing higher concentration of ethanol. The sodium counter-ion of the phenolate and the chlorine of cinnamyl chloride may be in close vicinity throughout the reaction pathway in ethanol-rich aqueous solutions as in transition state $\mathbf{A}$, which leads to $1 \mathbf{c}$ (Scheme 2). 
Table 2. Cinnamylation of phloroglucinol in aqueous solutions<smiles>[R]C(C)(C)O[Na]</smiles>

\begin{tabular}{|c|c|c|c|c|}
\hline \multirow[t]{2}{*}{ Entry } & \multirow[t]{2}{*}{ Conditions } & \multirow[t]{2}{*}{$x$} & \multicolumn{2}{|c|}{ Yields (\%) } \\
\hline & & & 1c & 1d \\
\hline 1 & Phosphate buffer $0.2 \mathrm{M}, \mathrm{pH} 7.8$ & 2 & 35 & 35 \\
\hline 2 & $\mathrm{NaOH}$ ( 1.25 equiv.), $\mathrm{H}_{2} \mathrm{O} / \mathrm{EtOH} 15 / 85$ (v/v) & 1.25 & 69 & Traces \\
\hline
\end{tabular}

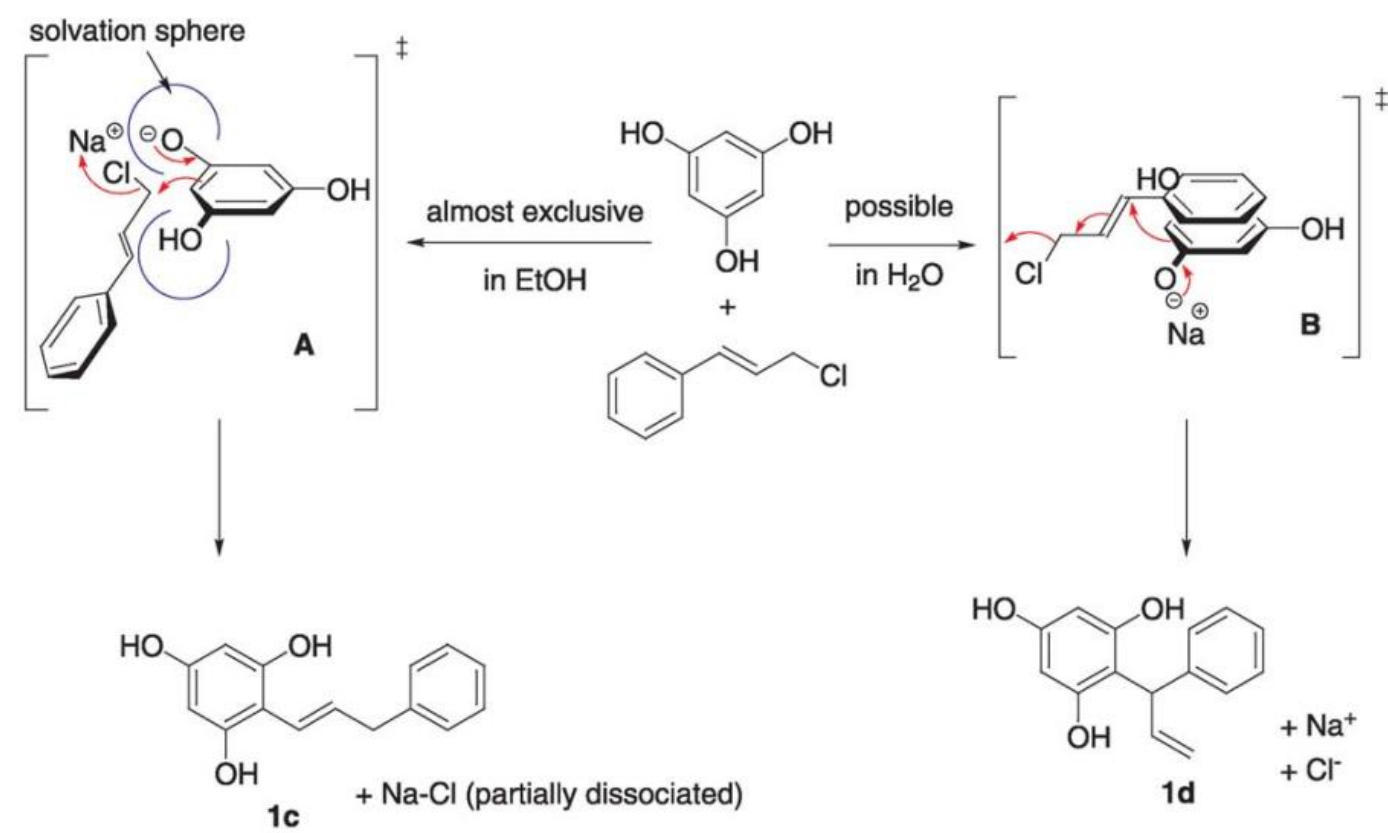

Scheme 2. Solvent-dependant transition states in the cinnamylation of phloroglucinol.

However, the strong hydrophobic effect and high cohesive energy density expected in water alone as a solvent should favor transition state $\mathbf{B}$ and thus produce $\mathbf{1 d} .{ }^{13}$ Yet, the phenols are also thoroughly solvated in water. This should favor the attack on the less crowded terminal position of the alkyl halide leading to 1c. These two opposing effects, hydrophobicity and solvation of the phenols, may account for the absence of selectivity in water.

With this result in hand, we then synthesized the advanced intermediate of catechin 1e starting from the highly hydrophobic functionalized cinnamyl chloride 3 (Table 3 ). This compound is efficiently synthesized in four steps starting from the commercially available 3,4-dihydroxybenzaldehyde (Scheme 3). The cinnamyl chloride $\mathbf{3}$ was then reacted with the phloroglucinol under a variety of aqueous ethanolic conditions (Table 3). 
Table 3. Synthesis of an advanced intermediate of catechin

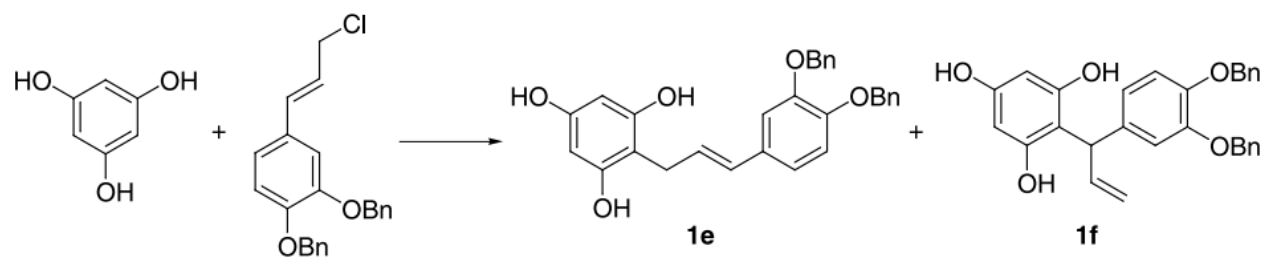

3 (x eq.)

\begin{tabular}{|c|c|c|c|c|}
\hline & \multirow[t]{2}{*}{ Conditions } & \multirow[t]{2}{*}{$x$} & \multicolumn{2}{|c|}{ Yields (\%) } \\
\hline & & & 1e & 1f \\
\hline 1 & $\mathrm{NaOH}$ (1.3 equiv.), $\mathrm{EtOH}_{90 \%}$ (vol.), $2 \mathrm{~h}$ & 1.25 & 0 & 0 \\
\hline 2 & $\mathrm{NaOH}$ (1.3 equiv.), $\mathrm{EtOH}_{90 \%}$ (vol.), $0.1 \mathrm{~h}$ & 1.25 & 45 & 12 \\
\hline 3 & $\mathrm{NaOH}$ ( 2 equiv.), EtOH/ $\mathrm{H}_{2} \mathrm{O} / \mathrm{THF} 72 / 14 / 14,20-50^{\circ} \mathrm{C}, 9 \mathrm{~h}$ & $0.33^{\mathrm{a}}$ & 53 & Traces \\
\hline
\end{tabular}

a 3 in a minimum of THF was added slowly to the reaction over a $4 \mathrm{~h}$ period.

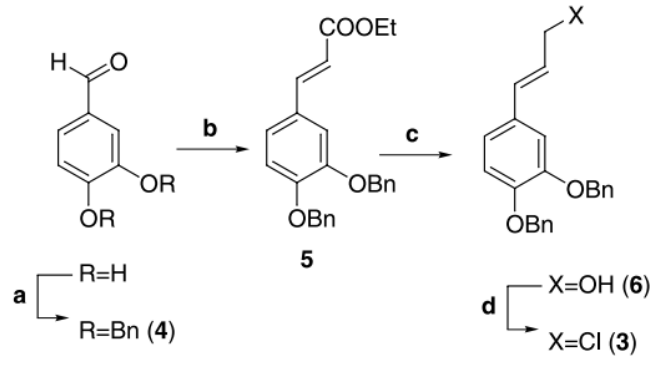

Scheme 3. Synthesis of the cinnamyl chloride 3. Reagents: (a) $\mathrm{NaH}, \mathrm{BnBr}$, DMF; (b) $\mathrm{NaH}$, triethylphosphonoacetate, THF; (c) $\mathrm{LAH}, \mathrm{Et}_{2} \mathrm{O},-15^{\circ} \mathrm{C}$;

(d) $\mathrm{SOCl}_{2}, \mathrm{Net}_{3}, \mathrm{CH}_{2} \mathrm{Cl}_{2}, 0{ }^{\circ} \mathrm{C}$

In contrast to allyl bromide and cinnamyl chloride, the substituted cinnamyl chloride $\mathbf{3}$ is not soluble in ethanol or water. Consequently, no adduct is formed under the conditions optimized with cinnamyl chloride (entry 1). Under ultrasonic irradiation, the desired product $\mathbf{1 e}$ is formed, yet not selectively (entry 2), the other regioisomer $\mathbf{1} \mathbf{f}$ being obtained in substantial amounts. ${ }^{14}$ When a solution of $\mathbf{3}$ in a minimum of THF is added slowly to the phloroglucinol in aqueous ethanol under gentle heating, only trace amounts of the undesired $\mathbf{1} \mathbf{f}$ are observed and $\mathbf{1 e}$ is obtained pure in a satisfactory $53 \%$ yield after flash chromatography (entry 3). This product has already been synthesized in low yield (17\%) from phloroglucinol and the corresponding palladium $p$ acetate. ${ }^{8}$ This advanced intermediate of natural flavonoids is obtained in our case in $53 \%$ yield under very simple and straightforward conditions.

In conclusion, a mild, high-yielding C-specific and monoselective alkylation of phloroglucinol with activated alkyl halides has been developed. The $\mathrm{C}$-specificity of this reaction comes from the fact that both phloroglucinol and activated alkyl halides favor C-alkylation. On the other hand, the solubility of mono-C-adducts are limited in water, thereby, preventing over-alkylation reactions and giving good mono-alkylation selectivity. With minor changes in the experimental conditions, these aqueous conditions have been utilized with highly hydrophobic substrates to afford an advanced intermediate of catechin. The subsequent epoxidation of the double bond of $1 \mathrm{e}$ has not been successful so far due to the high reactivity of the phloroglucinol toward oxidants. Yet, preliminary results indicate that iodination of the double bond is feasible. We are now concentrating our efforts on trying to make this reaction more selective and then achieve a straightforward, protection-free, total synthesis of catechin.

\section{Experimental}

\subsection{General}

3.1.1. 2-Allylphloroglucinol (1a). To a solution of phloroglucinol.2 $\mathrm{H} 2 \mathrm{O}(0.1 \mathrm{~g}, 0.61 \mathrm{mmol})$ in $10.98 \mathrm{~mL} 0.2 \mathrm{M} \mathrm{Na}_{2} \mathrm{HPO}_{4}$ and $1.02 \mathrm{~mL}$ of $0.2 \mathrm{M}$ $\mathrm{NaH}_{2} \mathrm{PO}_{4}$ is added the allyl bromide $(0.21 \mathrm{~mL}, 2.44 \mathrm{mmol})$. The reaction is stirred for $3 \mathrm{~h}$ and the aqueous phase is extracted twice with ether. The combined organic layers are then washed with brine, dried over $\mathrm{Na}_{2} \mathrm{SO}_{4}$, filtered and concentrated under vacuum. The residue was purified by flash chromatography on silica gel (25-35\% AcOEt/hexane). $\mathrm{C}_{9} \mathrm{H}_{10} \mathrm{O}_{3}(166.06) ; \mathrm{R}_{\mathrm{f}} 0.45$ (40\% AcOEt/hexane); ${ }^{1} \mathrm{H}$ $\left(200 \mathrm{MHz}, \varepsilon \mathrm{CD}_{3} \mathrm{OD} / \mathrm{CDCl}_{3}\right): \delta 3.34\left(\mathrm{~d},{ }^{3} \mathrm{~J}=5.2 \mathrm{~Hz}, 2 \mathrm{H}, \mathrm{H} 5\right), 5.00-5.14\left(\mathrm{~m}, 2 \mathrm{H}, \mathrm{H}_{7}\right), 5.85-6.07\left(\mathrm{~m}, 1 \mathrm{H}, \mathrm{H}_{6}\right), 5.91\left(\mathrm{~s}, 2 \mathrm{H}, \mathrm{H}_{2}\right) .{ }^{13} \mathrm{C}(75 \mathrm{MHz}, \varepsilon$ 
$\left.\mathrm{CD}_{3} \mathrm{OD} / \mathrm{CDCl}_{3}\right): \delta 27.6,96.2,104.6,116.0,136.5,153.5,154.4 . \mathrm{IR}$ (neat): $v_{\max }=3454$ (br, OH), 2924 (Ar.), 1621 (Ar-O), 1452,1212 (br), $1112 \mathrm{~cm}^{-1}$. MS $\left(\mathrm{NH}_{4}^{+}\right): \mathrm{m} / \mathrm{z}: 167[\mathrm{M}+\mathrm{H}]^{+}$.

3.1.2. 2,4-Diallylphloroglucinol (2a). $\mathrm{C}_{12} \mathrm{H}_{14} \mathrm{O}_{3}$ (206.24); $\mathrm{R}_{\mathrm{f}} \mathrm{O} .7$ (60\% AcOEt/hexane); ${ }^{1} \mathrm{H}\left(200 \mathrm{MHz}, \mathrm{CDCl}_{3}\right): \delta 3.42(\mathrm{~m}, 4 \mathrm{H}), 5.13-5.25(\mathrm{~m}, 4 \mathrm{H})$, 5.94-6.07 (m, 2H), $6.01(\mathrm{~s}, 1 \mathrm{H}) ;{ }^{13} \mathrm{C}\left(75 \mathrm{MHz}, \mathrm{CDCl}_{3}\right): \delta 27.1,95.8,104.2,115.5,136.6,155.5,155.9 ; \mathrm{IR}: v_{\max }=3492$ (br, OH), 2924 (Ar.), 1623 (Ar-O), 1464, $1150 \mathrm{~cm}^{-1}$; MS $\left(\mathrm{NH}_{4}^{+}\right): \mathrm{m} / \mathrm{z}: 207[\mathrm{M}+\mathrm{H}]^{+}$.

3.1.3. 2-Benzylphloroglucinol (1b). Same procedure as for 1a (benzyl bromide as the electrophile). $\mathrm{C}_{13} \mathrm{H}_{12} \mathrm{O}_{3}$ (216.23); $\mathrm{Rf}_{\mathrm{f}} 0.4$ (60\% AcOEt/hexane); ${ }^{1} \mathrm{H}\left(200 \mathrm{MHz}, \varepsilon \mathrm{CD}_{3} \mathrm{OD} / \mathrm{CDCl}_{3}\right): \delta 3.96(\mathrm{~s}, 2 \mathrm{H}), 5.95(\mathrm{~s}, 2 \mathrm{H}), 7.12-7.26(\mathrm{~m}, 5 \mathrm{H}) ;{ }^{13} \mathrm{C}\left(50 \mathrm{MHz}, \varepsilon \mathrm{CD}_{3} \mathrm{OD} / \mathrm{CDCl}_{3}\right): \delta 28.4$, 96.0, 106.5, 126.2, 128.2, 128.6, 140.3, 155.4, 155.8; IR (neat): $v_{\max }=3359$ (br, OH), 2927 (Ar.), 1615 (br, Ar-O), 1456, 1144 cm ${ }^{-1}$; MS $\left(\mathrm{NH}_{4}{ }^{+}\right): \mathrm{m} / \mathrm{z}: 217(100)[\mathrm{M}+\mathrm{H}]^{+}, 234(49.8)\left[\mathrm{M}+\mathrm{NH}_{4}\right]^{+}, 251(10.8)\left[\mathrm{M}+\mathrm{NH}_{3}+\mathrm{NH}_{4}\right]^{+}$.

3.1.4. 2,4-Dibenzylphloroglucinol (2b). $\mathrm{C}_{20} \mathrm{H}_{18} \mathrm{O}_{3}$ (306.36); $\mathrm{Rf} 0.7$ (60\% AcOEt/hexane); ${ }^{1} \mathrm{H}\left(200 \mathrm{MHz}, \mathrm{CDCl}_{3}\right): \delta 3.99(\mathrm{~s}, 4 \mathrm{H}), 4.81(\mathrm{~s}, 3 \mathrm{H}, \mathrm{OH})$, $5.99(\mathrm{~s}, 1 \mathrm{H}), 7.12-7.30(\mathrm{~m}, 10 \mathrm{H}) ;{ }^{13} \mathrm{C}\left(50 \mathrm{MHz}, \mathrm{CDCl}_{3}\right): \delta 28.9,96.2,106.7,126.4,128.2,128.7,139.8,153.4,154.1 ; \mathrm{IR}$ (neat): $v_{\max }=3526$ (br, OH), 3028, 2924 (Ar.), 1619 (br, Ar-O), 1447, 1186, $1039 \mathrm{~cm}^{-1}$; MS $\left(\mathrm{NH}_{4}^{+}\right): \mathrm{m} / \mathrm{z}: 307(100)[\mathrm{M}+\mathrm{H}]^{+}, 323(54.6)\left[\mathrm{M}+\mathrm{NH}_{4}\right]^{+}$.

3.1.5. 2-Cinnamylphloroglucinol (1c). The cinnamyl chloride (7.62 mL, $54.00 \mathrm{mmol})$ is added to the phloroglucinol $2 \mathrm{H}_{2} \mathrm{O}(7 \mathrm{~g}, 43.17 \mathrm{mmol})$ in solution in $200 \mathrm{~mL}$ of ethanol and $25 \mathrm{~mL}$ of $2 \mathrm{M} \mathrm{NaOH}$. After $3 \mathrm{~h}$, the ethanol is partially evaporated under reduced pressure. The resulting aqueous solution is first washed with $200 \mathrm{~mL}$ of hexane and extracted three times with methylene chloride. The combined organic layers are then washed with brine, dried over $\mathrm{Na}_{2} \mathrm{SO}_{4}$, filtered and concentrated under vacuum. The residue was purified by flash chromatography on silica gel (25-40\% AcOEt/hexane). $\mathrm{C}_{15} \mathrm{H}_{14} \mathrm{O}_{3}$ (242.27); $\mathrm{Rf}_{\mathrm{f}} 0.45$ (60\% AcOEt/hexane); ${ }^{1} \mathrm{H}(200 \mathrm{MHz}, \varepsilon$ $\left.\mathrm{CD}_{3} \mathrm{OD} / \mathrm{CDCl}_{3}\right): \delta 3.57\left(\mathrm{~d},{ }^{3} \mathrm{~J}=5.4 \mathrm{~Hz}, 2 \mathrm{H}\right), 6.01(\mathrm{~s}, 2 \mathrm{H}), 6.36\left(\mathrm{dt},{ }^{3} \mathrm{~J}=15.9 \mathrm{~Hz}, 3 \mathrm{~J} 2 \frac{1}{4} / 5.6 \mathrm{~Hz}, 1 \mathrm{H}\right), 6.53\left(\mathrm{~d},{ }^{3} \mathrm{~J}=15.9 \mathrm{~Hz}, 1 \mathrm{H}\right), 7.22-7.39(\mathrm{~m}, 5 \mathrm{H})$; ${ }^{13} \mathrm{C}\left(75 \mathrm{MHz}, \varepsilon \mathrm{CD}_{3} \mathrm{OD} / \mathrm{CDCl}_{3}\right)$ : d 26.2, 96.0, 104.7, 126.2, 127.2, 128.0, 128.5, 130.7, 137.4, 155.4, 155.8; IR (neat): $v_{\max }=3381$ (br, OH), 2986, 2870 (Ar.), 1612 (Ar-O), $1142 \mathrm{~cm}^{-1}$; MS $\left(\mathrm{NH}_{4}^{+}\right): \mathrm{m} / \mathrm{z}: 243$ (56.9) [M+H] $]^{+}, 260$ (100) [M+NH$]^{+}, 277$ (20.3) [M+NH$\left.+\mathrm{NH}_{4}\right]^{+}$.

3.1.6. 2-(1-Phenyl-allyl)-phloroglucinol (1d). $\mathrm{C}_{15} \mathrm{H}_{14} \mathrm{O}_{3}$ (242.27); $\mathrm{R}_{\mathrm{f}} 0.5\left(60 \% \mathrm{AcOEt} /\right.$ hexane); ${ }^{1} \mathrm{H}\left(300 \mathrm{MHz}, \varepsilon \mathrm{CD}_{3} \mathrm{OD} / \mathrm{CDCl}_{3}\right): \delta 5.07-5.39$ (m, $2 \mathrm{H}), 5.21(\mathrm{br} \mathrm{s}, 2 \mathrm{H}, \mathrm{OH}), 5.31\left(\mathrm{~d},{ }^{3} \mathrm{~J}=5.9 \mathrm{~Hz}, 1 \mathrm{H}\right), 5.96(\mathrm{~s}, 2 \mathrm{H}), 7.24-7.34(\mathrm{~m}, 5 \mathrm{H}) ; \mathrm{IR}$ (neat): $v_{\max }=3446$ (br, OH), 2983 (Ar.), 1615 (Ar-O), $1217 \mathrm{~cm}^{-1} ; \mathrm{MS}\left(\mathrm{NH}_{4}{ }^{+}\right): \mathrm{m} / \mathrm{z}: 243[\mathrm{M}+\mathrm{H}]^{+}, 260\left[\mathrm{M}+\mathrm{NH}_{4}\right]^{+}$.

3.1.7. 2-[3-(3,4-Bisbenzyloxy-phenyl)-allyl]-phloroglucinol (1e). The cinnamyl chloride $3(0.3 \mathrm{~g}, 0.82 \mathrm{mmol})$ in $1.5 \mathrm{~mL}$ of THF is slowly added $(0.35 \mathrm{~mL} / \mathrm{h})$ to the phloroglucinol $2 \mathrm{H}_{2} \mathrm{O}(0.4 \mathrm{~g}, 2.47 \mathrm{mmol})$ in $8 \mathrm{~mL}$ of ethanol and $1.5 \mathrm{~mL}$ of water and $\mathrm{NaOH}(0.2 \mathrm{~g}, 5 \mathrm{mmol})$. The reaction is stirred at $50{ }^{\circ} \mathrm{C}$ for $4 \mathrm{~h}$ and the ethanol is partially evaporated under reduced pressure. The resulting aqueous solution is first washed with $200 \mathrm{~mL}$ of hexane and extracted three times with methylene chloride. The combined organic layers are then washed with brine, dried over $\mathrm{Na}_{2} \mathrm{SO}_{4}$, filtered and concentrated under vacuum. The residue was purified by flash chromatography on silica gel (30-40\% AcOEt/hexane). $\mathrm{C}_{29} \mathrm{H}_{26} \mathrm{O}_{5}$ (454.51); $\mathrm{R}_{\mathrm{f}} 0.45$ (60\% AcOEt/hexane); ${ }^{1} \mathrm{H}\left(300 \mathrm{MHz}, \varepsilon \mathrm{CD}_{3} \mathrm{OD} / \mathrm{CDCl}_{3}\right): \delta 3.39\left(\mathrm{~d},{ }^{3} \mathrm{~J}=5.0 \mathrm{~Hz}, 2 \mathrm{H}\right)$, $5.02,5.03(\mathrm{~s}, 4 \mathrm{H}), 5.89(\mathrm{~s}, 2 \mathrm{H}), 6.11\left(\mathrm{dt},{ }^{3} \mathrm{~J}=15.9 \mathrm{~Hz},{ }^{3} \mathrm{~J}=5.9 \mathrm{~Hz}, 1 \mathrm{H}\right), 6.28\left(\mathrm{~d},{ }^{3} \mathrm{~J}=15.9 \mathrm{~Hz}, 1 \mathrm{H}\right), 6.78\left(\mathrm{dd},{ }^{3} \mathrm{~J}=8.4 \mathrm{~Hz},{ }^{4} \mathrm{~J}=1.9 \mathrm{~Hz}, 1 \mathrm{H}\right), 6.84(\mathrm{~d}$, $\left.{ }^{3} \mathrm{~J}=8.4 \mathrm{~Hz}, 1 \mathrm{H}\right), 6.97\left(\mathrm{~d},{ }^{4} \mathrm{~J}=1.9 \mathrm{~Hz}, 1 \mathrm{H}\right), 7.23-7.41(\mathrm{~m}, 10 \mathrm{H}) ;{ }^{13} \mathrm{C}\left(75 \mathrm{MHz}, \varepsilon \mathrm{CD}_{3} \mathrm{OD} / \mathrm{CDCl}_{3}\right): \delta 26.8,72.3,72.4,95.4,106.1,113.5,116.3$, 120.5, 128.4, 128.5, 128.6, 129.1, 129.2, 133.7, 138.3, 148.7, 149.9, 156.9, 157.4; IR (neat): $v_{\max }=3388$ (br, OH), 3032,2925 (Ar.), 1606 (Ar-O), 1509, 1262, $1133 \mathrm{~cm}^{-1}$; MS $\left(\mathrm{NH}_{4}^{+}\right): \mathrm{m} / \mathrm{z}: 472\left[\mathrm{M}+\mathrm{NH}_{4}\right]^{+}$.

3.1.8. 2-[3-(3,4-Bisbenzyloxy-phenyl)-allyl]-phloroglucinol (1f). $\mathrm{C}_{29} \mathrm{H}_{26} \mathrm{O}_{5}(454.51) ; \mathrm{Rf}_{\mathrm{f}} 0.55$ (60\% AcOEt/ hexane); ${ }^{1} \mathrm{H}(300 \mathrm{MHz}, \mathrm{CDCl}): \delta 5.01-$ $5.28(\mathrm{~m}, 2 \mathrm{H}), 5.07,5.10(\mathrm{~s}, 4 \mathrm{H}), 5.19\left(\mathrm{~d},{ }^{3} \mathrm{~J}=6.2 \mathrm{~Hz}, 1 \mathrm{H}\right), 5.92(\mathrm{~s}, 2 \mathrm{H}), 6.30-6.41(\mathrm{~m}, 1 \mathrm{H}), 6.77-6.90(\mathrm{~m}, 3 \mathrm{H}), 7.26-7.43(\mathrm{~m}, 10 \mathrm{H}) ; \mathrm{MS}$ $\left(\mathrm{NH}_{4}^{+}\right): m / z: 472\left[\mathrm{M}+\mathrm{NH}_{4}\right]^{+}$.

3.1.9. 3,4-Dibenzyloxybenzaldehyde (4). A first portion of sodium hydride (60\%, $7 \mathrm{~g})$ is added to the 3,4-dihydroxybenzaldehyde (18.65 $\mathrm{g}$, $135 \mathrm{mmol})$ in $300 \mathrm{~mL}$ of dry DMF. After the evolution of gas had ceased, the benzyl bromide $(32.92 \mathrm{~mL})$ is added dropwise on the solution. After $1 \mathrm{~h}$, the rest of the $\mathrm{NaH}$ is added $(5.88 \mathrm{~g}, 297 \mathrm{mmol}$ total). The reaction is stirred for four additional hours and $600 \mathrm{~g}$ of ice is added to the reaction mixture. The aqueous solution is extracted three times with ether. The combined organic layers are then washed with brine, dried over $\mathrm{Na}_{2} \mathrm{SO}_{4}$, filtered and concentrated under vacuum. The brown solid thus obtained is triturated with methanol to afford $36.4 \mathrm{~g}(85 \%)$ of $4 . \mathrm{C}_{21} \mathrm{H}_{18} \mathrm{O}_{3}$ (318.37); $\mathrm{R}_{\mathrm{f}} 0.55$ (30\% AcOEt/ hexane); ${ }^{1} \mathrm{H}\left(200 \mathrm{MHz}, \mathrm{CDCl}_{3}\right): \delta 5.22(\mathrm{~s}, 2 \mathrm{H}), 5.26(\mathrm{~s}, 2 \mathrm{H})$, $7.03\left(\mathrm{~d},{ }^{3} \mathrm{~J}=8.0 \mathrm{~Hz}, 1 \mathrm{H}\right), 7.26-7.51(\mathrm{~m}, 11 \mathrm{H}), 9.82(\mathrm{~s}, 1 \mathrm{H}) ;{ }^{13} \mathrm{C}\left(50 \mathrm{MHz}, \mathrm{CDCl}_{3}\right): \delta 70.8,71.0,112.5,113.1,126.6,127.0,127.3,128.0$,

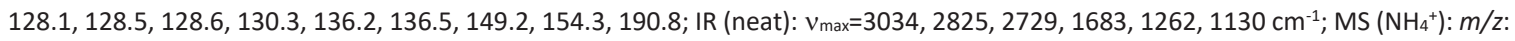
$319[\mathrm{M}+\mathrm{H}]^{+}$.

3.1.10. 3-(3,4-Bis-benzyloxy-phenyl)-acrylic acid ethyl ester (5). $\mathrm{NaH}(5.26 \mathrm{~g}, 130 \mathrm{mmol})$ is added to a solution of triethylphosphonoacetate $(24.05 \mathrm{~mL}, 120 \mathrm{mmol})$ in $300 \mathrm{~mL}$ of THF. After the evolution of gas had ceased, the 3,4- dibenzyloxybenzaldehyde (36.4 g, $114 \mathrm{mmol})$ is added and the reaction is stirred for $10 \mathrm{~min} .400 \mathrm{~g}$ of ice is added to the reaction mixture and the aqueous solution is extracted three times with ethyl acetate. The combined organic layers are then washed with brine, dried over $\mathrm{Na}_{2} \mathrm{SO}_{4}$, filtered and concentrated under vacuum. The residue was rapidly filtered (AcOEt) on a short pad of silica to afford $44.2 \mathrm{~g}(100 \%)$ of the acrylate. $\mathrm{C}_{25} \mathrm{H}_{24} \mathrm{O}_{4}(388.46) ; \mathrm{R}_{\mathrm{f}}$ 0.45 (20\% AcOEt/ hexane); ${ }^{1} \mathrm{H}\left(200 \mathrm{MHz}, \mathrm{CDCl}_{3}\right): \delta 1.33\left(\mathrm{t},{ }^{3} \mathrm{~J}=7.2 \mathrm{~Hz}, 3 \mathrm{H}\right), 4.25$ (q, $\left.{ }^{3} \mathrm{~J}=7.2 \mathrm{~Hz}, 2 \mathrm{H}\right), 5.19(\mathrm{~s}, 2 \mathrm{H}), 5.20(\mathrm{~s}, 2 \mathrm{H}), 6.25(\mathrm{~d}$, $\left.{ }^{3} J=15.9 \mathrm{~Hz}, 1 \mathrm{H}\right), 6.92\left(\mathrm{~d},{ }^{3} J=8.4 \mathrm{~Hz}, 1 \mathrm{H}\right), 7.07\left(\mathrm{dd},{ }^{3} \mathrm{~J}=8.4 \mathrm{~Hz},{ }^{4} \mathrm{~J}=2.2 \mathrm{~Hz}, 1 \mathrm{H}\right), 7.13\left(\mathrm{~d},{ }^{4} \mathrm{~J}=2.2 \mathrm{~Hz}, 1 \mathrm{H}\right), 7.32-7.48(\mathrm{~m}, 10 \mathrm{H}), 7.80$ (d, ${ }^{3} \mathrm{~J}=15.9$ $\mathrm{Hz}, 1 \mathrm{H}) ;{ }^{13} \mathrm{C}\left(50 \mathrm{MHz}, \mathrm{CDCl}_{3}\right): \delta 14.4,60.4,71.0,71.3,113.7,114.3,116.2,122.8,127.2,127.3,128.0,128.6,136.8,144.4,148.9,151.0$, 167.2. IR (neat): $v_{\max }=2972,2926,2866,1739,1716,1511,1230 \mathrm{~cm}^{-1}$. MS $\left(\mathrm{NH}_{4}{ }^{+}\right): \mathrm{m} / \mathrm{z}: 389[\mathrm{M}+\mathrm{H}]^{+}$.

3.1.11. 3', 4'-Dibenzyloxycinnamyl alcohol (6). $\mathrm{LiAlH}_{4}(0.195 \mathrm{~g}, 5.15 \mathrm{mmol})$ is added over $5 \mathrm{~min}$ to a solution of the acrylate $(2.00 \mathrm{~g}, 5.15 \mathrm{mmol})$ in $60 \mathrm{~mL}$ anhydrous ether at $-15^{\circ} \mathrm{C}$ (RM: to avoid the precipitation of the acrylate, the addition must start right after the flask is cooled). 
The reaction is stirred for $2 \mathrm{~h}$ and a few drops of conc. $\mathrm{Na}_{2} \mathrm{~S}_{2} \mathrm{O}_{5}$ and $5 \mathrm{~g}$ of $\mathrm{Na}_{2} \mathrm{SO}_{4}$ are added. The residue is rapidly filtered (AcOEt) on a short pad of silica to afford $1.34 \mathrm{~g}(75 \%)$ of pure $6 . \mathrm{C}_{23} \mathrm{H}_{22} \mathrm{O}_{3}(346.42) ; \mathrm{Rf}_{\mathrm{f}} 0.25$ (40\% AcOEt/hexane); ${ }^{1} \mathrm{H}\left(200 \mathrm{MHz}, \mathrm{CDCl}_{3}\right): \delta 4.27$ (dd, $\left.{ }^{3} \mathrm{~J}=5.9 \mathrm{~Hz},{ }^{4} \mathrm{~J}=1.5 \mathrm{~Hz}, 2 \mathrm{H}\right), 5.18,5.17(\mathrm{~s}, 4 \mathrm{H}), 6.18\left(\mathrm{dt},{ }^{3} \mathrm{~J}=15.9 \mathrm{~Hz},{ }^{3} \mathrm{~J}=5.9 \mathrm{~Hz}, 1 \mathrm{H}\right), 6.50$ (dt, $\left.{ }^{3} \mathrm{~J}=15.9 \mathrm{~Hz},{ }^{4} \mathrm{~J}=1.5 \mathrm{~Hz}, 1 \mathrm{H}\right), 6.90-7.04(\mathrm{~m}, 3 \mathrm{H})$, $7.28-7.51(\mathrm{~m}, 10 \mathrm{H}) ;{ }^{13} \mathrm{C}\left(50 \mathrm{MHz}, \mathrm{CDCl}_{3}\right): \delta 61.9,69.4,69.5,111.1,113.1,118.5,125.0,125.4,125.5,126.0,126.1,126.7,126.8,128.6$, 129.0, 135.4, 147.0, 147.2; IR (neat): $v_{\max }=3065(\mathrm{br}, \mathrm{OH}), 3035,2920,1512,1259 \mathrm{~cm}^{-1}$; MS $\left(\mathrm{NH}_{4}^{+}\right): \mathrm{m} / \mathrm{z}: 364\left[\mathrm{M}+\mathrm{NH}_{4}\right]^{+}$.

3.1.12. 3-(3,4-Bis-benzyloxy-phenyl)-1-chloro-prop-2- ene (3). Thionyl chloride $(0.93 \mathrm{~mL}, 12.71 \mathrm{mmol})$ is added dropwise to the cinnamyl alcohol $(4 \mathrm{~g}, 11.56 \mathrm{mmol})$ and triethylamine $(1.85 \mathrm{~mL}, 13.29 \mathrm{mmol})$ in $100 \mathrm{~mL}$ of dichloromethane at $0{ }^{\circ} \mathrm{C}$. After $1 \mathrm{~h}, 100 \mathrm{~mL}$ of water is added and the resulting aqueous solution is extracted three times with methylene chloride. The combined organic layers are then washed with brine, dried over $\mathrm{Na}_{2} \mathrm{SO}_{4}$, filtered and concentrated under vacuum. The residue was purified by a rapid flash chromatography on silica gel $\left(50 \%\right.$ AcOEt/hexane) to give $3.72 \mathrm{~g}(88 \%)$ of the cinnamyl chloride $3 . \mathrm{C}_{23} \mathrm{H}_{21} \mathrm{Cl}_{1} \mathrm{O}_{2}(364.86) .{ }^{1} \mathrm{H}(200 \mathrm{MHz}$, $\left.\mathrm{CDCl}_{3}\right): \delta 4.22\left(\mathrm{dd},{ }^{3} \mathrm{~J}=7.3 \mathrm{~Hz},{ }^{3} \mathrm{~J}=1.3 \mathrm{~Hz}, 2 \mathrm{H}\right), 5.18,(\mathrm{~s}, 4 \mathrm{H}), 6.14\left(\mathrm{dt},{ }^{3} \mathrm{~J}=15.7 \mathrm{~Hz},{ }^{3} \mathrm{~J}=7.3 \mathrm{~Hz}, 1 \mathrm{H}\right), 6.55\left(\mathrm{~d},{ }^{3} \mathrm{~J}=15.7 \mathrm{~Hz}, 1 \mathrm{H}\right), 6.88-7.03(\mathrm{~m}$, $3 \mathrm{H}), 7.31-7.50(\mathrm{~m}, 1 \mathrm{OH}) ;{ }^{13} \mathrm{C}\left(50 \mathrm{MHz}, \mathrm{CDCl}_{3}\right): \delta 46.1,71.6,71.9,113.6,115.3,121.1,123.6,127.7,127.8,128.3,128.9,130.0,134.3$, 137.5, 149.5, 149.8; IR (neat): $v_{\max }=3032,2936,1511,1263,1135 \mathrm{~cm}^{-1} ; \mathrm{MS}\left(\mathrm{NH}_{4}^{+}\right): \mathrm{m} / \mathrm{z}: 382\left[\mathrm{M}+\mathrm{NH}_{4}\right]^{+}$.

\section{Acknowledgements}

We thank Shannon Biros for reviewing this manuscript and the Ministère de la recherche et de l'enseignement supérieur for financial support through a MRE grant to Arnaud Gissot.

\section{References and notes}

1. (a) Jovanovic, S. V.; Steenken, S.; Tosic, M.; Marjanovic, B.; Simic, M. G. J. Am. Chem. Soc. 1994, 116, 4846. (b) Wright, J. S.; Johnson, E. R.; DiLabio, G. A. J. Am. Chem. Soc. 2001, 123, 1173.

2. (a) Kawamoto, H.; Nakatsubo, F.; Murakami, K. J. Wood Chem. Technol. 1989, 9, 35. (b) Nay, B.; Arnaudinaud, V.; Peyrat, J. F.; Nuhrich, A.; Deffieux, G.; Mérillon, J. M.; Vercauteren, J. Eur. J. Org. Chem. 2000, 1279. (c) Li, L.; Chan, T. H. Org. Lett. 2001, 3, 739. (d) Kozikowski, A. P.; Tückmantel, W.; Hu, Y. J. Org. Chem. 2001, 66, 1287.

3. Curtis, W. D.; Stoddart, J. F.; Jones, G. H. J. Chem. Soc. Perkin Trans. 1 1977, 785.

4. (a) Deme, E. J. Org. Chem. 1976, 41, 3769. (b) Büchi, G.; Francisco, M. A.; Liesch, J. M.; Schuda, P. J. Am. Chem. Soc. 1981, 103, 3497. (c) Kawamoto, H.; Nakatsubo, F.; Murakami, K. Synth. Commun. 1996, 26, 531. (d) Nagvekar, D. S.; Gibson, H. W. Org. Prep. Proced. Int. 1997, 29, 240.

5. (a) Nakahira, H.; Sunagawa, M. Tetrahedron Lett. 1997, 38, 4443. (b) Forget-Champagne, D.; Mondon, M.; Fonteneau, N.; Gesson, J. P. Tetrahedron Lett. 2001, 42, 7229.

6. These results ruled out the possibility that the previous allylphloroglucinol was obtained following a Claisen rearrangement of the O-allyl phloroglucinol.

7. O/C-benzylation=8/2 according to the NMR analysis of the crude mixture.

8. Le Noble, W. J. Synthesis 1970, 1.

9. Nay, B.; Peyrat, J. F.; Vercauteren, J. Eur. J. Org. Chem. 1999, 2231.

10. Gissot A.; Wagner A.; Mioskowski C. Unpublished results.

11. Jurd and coll. have reported the condensation of phloroglucinol with cinnamyl alcohol in aqueous acetic acid. Yet, the adduct is only described as its triacetate ester. It is not clear whether the protection of the phenols was necessary or was just used to obtain crystalline products. Yet, from our own experience it is likely that the unprotected adduct might be difficult to isolate in that case as we have always experienced degradation of $1 \mathrm{c}$ during the work-up procedure when the reaction was carried out under acidic conditions. See Jurd, L. Tetrahedron 1969, 25, 1407.

12. Nay, B.; Collet, M.; Lebon, M.; Cheze, C.; Vercauteren, J. Tetrahedron Lett. 2002, 43, 2675.

13. Lubineau, A.; Augé, J.; Queneau, Y. Synthesis 1994, 741.

14. As seen before, the different cinnamyl phloroglucinols such as $1 \mathrm{c}$ or $1 \mathbf{e}$ are acid-sensitive. They can nevertheless be purified on silica gel provided a fast elution of the products. Hence, both regioisomers $\mathbf{1 e}$ and $\mathbf{1} \mathbf{f}$ are barely separable on silica gel. 